\begin{tabular}{l|l|l} 
Jurnal Eksplorasi Akuntansi & Vol. 1, No 4, Seri A, November 2019, Hal 1666-1686
\end{tabular} \mid $\begin{aligned} & \text { ISSN : 2656-3649 (Online) } \\
& \text { http://jea.ppj.unp.ac.id/index.php/jea/issue/view/14 }\end{aligned}$

\title{
ANALISIS PENGEMBANGAN ELECTRONIC GOVERNMENT MELALUI PENYELENGGARAAN WEBSITE DI PEMERINTAHAN DAERAH KABUPATEN PADANG PARIAMAN
}

\author{
Eka Rolania Batubara1, Herlina Helmy ${ }^{2}$ \\ ${ }^{1}$ Alumni Jurusan Akuntansi Fakultas Ekonomi, Universitas Negeri Padang \\ ${ }^{2}$ Jurusan Akuntansi Fakultas Ekonomi, Universitas Negeri Padang \\ *Korespondensi: ekarolania97@yahoo.co.id
}

\begin{abstract}
This study aims to further examine how the development of e-government in government institutions and what obstacles are faced in implementing e-government. This research uses interpretive qualitative. The process of this research is interactive and means that is not measured based on statistical data and the aim is to explore various information obtained in more depth and to get things implied by the data collection conducted in triangulation. This data analysis is inductive and the results of qualitative research emphasize the meaning of generalization. This interpretive research method seeks to formulate a question then be analyzed based on the perception questions of the participants studied. The research was conducted in one of the government agencies namely the Office of Communication and Information in Padang Pariaman Regency. To find out the extent of e-government development in Padang Pariaman Regency in this study using the results of studies and research from the Hardvard JFK School of Government, the elements of success which include support, capacity and value. The results of the study can be found that the development of e-government in Padang Pariaman is still not optimal. The development of e-government in Padang Pariaman Regency is also still hampered by several factors such as the lack of strong political will, the lack of availability of human resources and infrastructure as well as the lack of budget from the government so that the government of Padang Pariaman Regency needs to increase human resources and infrastructure to support the success of e-development government in Padang Pariaman Regency.
\end{abstract}

Keywords: E-government; Elements of e-Government Developmen; Inhibiting Factors

How to cite (APA $6^{\text {th }}$ style)

Barubara, E., R; Helmy, Herlina. (2019). Analisis Pengembangan Electronic Government Melalui Penyelenggaraan Website di Pemerintah Daerah Kabupaten Padang Pariaman. Jurnal Eksplorasi Akuntansi, 1(4), Seri A, 1666-1686.

\section{PENDAHULUAN}

Pelayanan publik di era otonomi daerah telah menjadi isu penting untuk implementasi penyelenggaraan pemerintahan di daerah. Hal ini terkait dengan upaya pemerintah daerah untuk mendukung terciptanya good governance. Pemerintah telah melakukan upaya untuk meningkatkan layanan publik terutama melalui penerapan teknologi informasi. Pemerintah menggunakan teknologi informasi dan komunikasi sebagai sarana untuk menyediakan informasi dan berfungsi agar layanan publik dapat lebih efektif dan efisien, lebih bertanggung jawab dan 
transparan pada proses tata kelola internal yang lebih terbuka untuk partisipasi publik dalam pengambilan keputusan dan proses penyediaan layanan publik kepada masyarakat (Heeks \& Bailur, 2007). Konsekuensinya terjadi transformasi administrasi pemerintahan dari traditional government menjadi electronic government (E-government).

Istilah E-government bukanlah hal baru, terutama di banyak negara maju. World Bank mendefinisikan E-government merupakan penggunaan alat teknologi pemerintah (seperti wide area network, internet dan mobile computing) yang memungkinkan pemerintah untuk mentransformasikan hubungan atau berinteraksi dengan masyarakat, dunia bisnis dan pemangku berkepentingan (Indrajit, 2006:6). Isu E-government ini menjadi perhatian, tidak hanya di negara negara maju, hal ini juga nenarik perhatian di negara-negara berkembang, salah satunya adalah Indonesia. Indonesia merupakan salah satu negara berkembang yang telah menerapkan $E$ government sejak dikeluarkannya Instruksi Presiden No. 6 tahun 2001 tentang Telematika yang menyatakan bahwa aparat pemerintah harus menggunakan teknologi telematika untuk mendukung tata pemerintahan yang baik. Aturan tersebut kemudian digantikan dengan dikeluarkannya Instruksi Presiden RI No. 3 Tahun 2003 Tentang Kebijakan Dan Strategi Nasional Pengembangan E-government yang merupakan langkah serius Pemerintah Indonesia untuk memanfaatkan teknologi informasi dan komukasi dalam menjalankan aktivitas pemerintahan.

Salah satu aplikasi E-government yang diterapkan oleh pemerintah daerah adalah melalui situs web. Pemerintahan baik secara terpusat dan regional, memiliki domain situs web sendiri untuk menyediakan akses publik kepada masyarakat (Moon \& Norris, 2005). Situs web sektor publik berperan penting dalam upaya meningkatkan transparansi, akuntabilitas, dan partisipasi publik serta sebagai sarana untuk menyediakan audiens yang lebih efektif dan efisien mengenai struktur proses informasi dan berbagai produk serta saluran bertujuan dalam berinteraksi dengan pemerintah (Bimber, 1999; Jun and Weare, 2010; La Porte, Demchak, and Friis, 2001; Musso, Weare, and Hale, 2000; Tolbert and mossberger, 2006; West, 2004 dalam Isni, Alisha, 2018).

Kenyataannya di lapangan bahwa masih banyak pemerintah daerah belum sepenuhnya memanfaatkan situs web sebagai sarana penyaluran informasi kepada publik. Sebagai contoh riset Agustin (2014) mengenai pengimplementasian Instruksi Mendagri nomor 188.52/1797/SJ tahun 2012 menemukan bahwa 10 dari 19 (56,23\%) pemkab maupun pemkot di propinsi Sumatera Barat belum memanfaatkan menu transparansi pengelolaan anggaran (TPA) yang tersedia pada website resmi pemkab maupun pemkot tersebut, untuk mempublikasikan secara lengkap dan konsisten dokumen-dokumen terkait pengelolaan anggaran daerah setiap tahunnya kepada publik.

Pemerintah daerah Kabupaten Padang Pariaman merupakan salah satu lembaga pemerintah yang telah mengimplementasikan E-government. Situs web Pemerintah Kabupaten Padang Pariaman juga belum menyediakan fasilitas interaksi seperti buku tamu, forum diskusi, chatting, online support, link kontak, dan polling. Pemerintah daerah belum dapat mengimplentasikan E-government dengan baik. Pengelolaan website di setiap otoritas perangkat daerah se-lingkungan Pemerintah Padang Pariaman masih belum optimal. Otoritas perangkat daerah yang ada di lingkungan Padang Pariaman hanya sebagian kecil yang memiliki situs website. Informasi yang disediakan oleh Pemerintah Kabupaten Padang Pariaman tidak sepenuhnya dapat diakses dan tidak lengkap, sehingga informasi yang dibutuhkan oleh masyarakat tidak terpenuhi dan menghambat pelaksanaan good governance kepada masyarakat terutama yang berkaitan dengan transparansi dan keterbukaan terkait dengan urusan pemerintah. 
Fenomena ini harus menjadi perhatian pemerintah daerah untuk memperbaiki kualitas website guna menerapkan E-government yang baik. Studi implementasi E-government harus berfokus mengenai bagaimana pengembangan E-government serta faktor-faktor kegagalan $E$ government (Alshawi dan Alalwany, 2009; Basu, 2004; Gao et al, 2013). Pemerintah harus memperhatikan semua masalah yang menyebabkan banyak kegagalan implementasi egovernment tersebut. Sebagai contoh, riset Agustin and Halmawati (2017) menemukan bukti empiris bahwa tidak optimalnya pengimplementasian Instruksi Mendagri nomor 188.52/1797/SJ tahun 2012 mengenai penggunaan menu transparansi pengelolaan anggaran (TPA) yang tersedia di website resmi pemkoab maupun pemkot di propinsi Sumatera Barat disebabkan karena minimnya unsur tekanan memaksa (coercive pressure) dalam produk hukum tersebut. Tidak ada kejelasan sanksi hukum yang akan diterima bagi pemkab/pemkot yang tidak menjalankan dengan sungguh-sungguh Instruksi Mendagri tersebut.

Penelitian ini dilakukan untuk meneliti lebih lanjut bagaimana pengembangan $E$ government di lembaga pemerintah. Untuk melihat bagaimana pelaksanaan E-government Pemerintahan Kabupaten Padang Pariaman, maka peneliti menggunakan indikator dari penelitian Nugraha (2018) yang mengacu pada buku Indrajit (2006:13-15; 2007:7-8) dimana terdapat tiga elemen penting dalam pengembangan E-government yaitu Support, Capital dan Value. Elemen pertama, Support merupakan keinginan pemerintah untuk menerapkan E-gov di Kabupaten Padang Pariaman, bukan hanya sekedar mengikuti trend saja seperti Political Will, Sosialisasi dan Kontinyuitas. Elemen Kedua, Capacity adalah bagaimana kemampuan atau kebudayaan dari pemerintah setempat dalam mewujudkan "impian" E-government terkait menjadi kenyataan seperti sumber daya finansial, sumber daya manusia, dan infrastruktur teknologi informasi. Elemen yang terakhir, elemen Value adalah dimana pemerintah harus benar-benar teliti dalam menerapkan E-gov, agar E-gov yang diterapkan ini dapat bermanfaat bagi masyarakat dan juga mereka yang berkepentingan serta faktor apa saja penghambat dalam penerapan E-government. Ketiga elemen ini, merupakan elemen penting dalam mengukseskan pengembangan $E$ government.

Penelitian ini nantinya akan merefleksi dan sejalan dengan yang dilakukan oleh Nugraha (2018) pada literaturnya yang menekankan perlunya penelitian mengenai analisis pengembangan E-government. Riset ini menggunakan pendekatan kualitatif dengan melakukan wawancara mendalam kepada pihak yang bertanggungjawab dalam pengelolaan website. Penelitian ini dilakukan untuk meneliti bagaimana pengembangan E-government di pemerintah kabupaten Padang Pariaman melalui situs web serta faktor-faktor dan kendala apa saja yang menghambat implementasi E-government.

Kontribusi dari penelitian ini adalah bahwa hasil penelitian dapat digunakan sebagai salah satu pedoman di masa depan untuk meningkatkan implementasi E-government melalui situs web. Secara teoritis, penelitian ini menunjukkan bagaimana pengembangan telah dilakukan oleh pemerintah dan dapat memberikan solusi yang tepat untuk memecahkan masalah yang ada untuk mencapai keberhasilan implementasi E-government di negara-negara berkembang, terutama dalam konteks pemerintah daerah dan meningkatkan kualitas layanan publik.

\section{REVIEW LITERATUR \\ Good Governance}

Governance didefinisikan sebagai mekanisme, praktik dan prosedur bagi pemerintah dan warga negara untuk mengatur sumber daya dan menyelesaikan masalah publik. Good governance sebagai penerapan manajemen pembangunan yang solid dan bertanggungjawab sesuai dengan 
prinsip-prinsip demokrasi dan pasar yang efisien, menghindari penyelewengan dana investasi, dan pencegahan korupsi secara politis dan administratif melalui penerapan displin anggaran dan penciptaan legal and political framework bagi pertumbuhan aktivitas usaha (Mardiasmo, 2009:18).

Good governance kini menjadi bagian dari wacana tentang pengembangan paradigma birokrasi dan pembangunan di masa depan. Menurut Mardiasmo (2009:18) menyebutkan tiga pilar yang saling berkaitan untuk mewujudkan good governance yaitu transparansi, partisipasi, dan akuntabilitas, dan lebih banyak elemen yang dapat mewujudkan good governance yaitu value of money (ekonomi, efisiensi, dan efektivitas).

\section{Electronic Government \\ Definisi e-Government}

E-government memiliki berbagai macam definisi dari berbagai lembaga dan pemerintahan. The World Bank Group menjelaskan bahwa e-Government sebagai berikut: "e-Government berhubungan erat dengan adanya penggunaan teknologi informasi (seperti wide area network, Internet dan mobile computing) oleh organisasi pemerintahan yang mempunyai kemampuan membentuk hubungan dengan warga negara, bisnis dan organisasi lain dalam pemerintahan.” (The World Bank Group, 2001).

Secara ringkas, dari berbagai definisi e-Government di atas, maka dapat disimpulkan bahwa e-Government adalah sebuah penggunaan teknologi informasi secara elektronis melalui Wide Area Network, Internet dan mobile computing dalam ruang lingkup penyelenggaraan pemerintahan yang tidak terbatas tempat dan waktu guna mengoptimalisasikan proses pelayanan publik yang efisien, transparan, dan efektif.

\section{Manfaat dan Tujuan e-Government}

E-government memiliki banyak manfaat guna menunjang efektivitas dan efisiensi pelayanan publik. Al Gore dan Tony Blair secara jelas dan terperinci menjelaskan manfaat yang dapat diperoleh dengan diterapkannya konsep E-government (Indrajit, 2006:8) antara lain:

1) Meningkatkan serta memperbaiki kualitas pelayanan publik pemerintah kepada stakeholdernya seperti masyarakat, kalangan bisnis, dan industri, terutama terkait dengan hal kinerja pemerintah, efektivitas dan efisiensi di kehidupan bernegara.

2) Meningkatkan transparansi, pengendalian, serta keterbukaan penyelenggaraan pemerintahan terkait dalam penerapan konsep good governance.

3) Adanya pengurangan signifikan total biaya administrasi, adanya relasi dan interaksi yang dikeluarkan pemerintah maupun kepada stakeholder-nya untuk keperluan kegiatan pemerintah sehari-hari.

4) Memberikan peluang pemerintah untuk mendapatkan sumber-sumber pendapatan yang baru melalui interaksinya dengan pihak-pihak yang berkepentingan.

5) Menciptakan suatu lingkungan masyarakat yang baru yang merupakan jawaban dari berbagai permasalahan yang dihadapi secara lebih cepat dan tepat yang sejalan dengan perubahan global dan tren.

6) Memberdayakan masyarakat dan pihak-pihak yang lain sebagai mitra pemerintah dalam proses pengambilan kebijakan publik secara merata dan demokratis.

\section{Tahapan e-Government}

Menurut Indrajit (2006) tahapan perkembangan implementasi e-government di Indonesia, dibagi menjadi empat: 
1) Booklet (to publish), memunculkan website daerah di internet. Tahapan ini, informasi dasar yang dibutuhkan masyarakat ditampilkan dalam website pemerintah.

2) Interaction, merupakan web daerah yang telah menyediakan fasilitas interaksi antara masyarakat dan pemerintah daerah. Pada tahapan ini, informasi yang ditampilkan lebih bervariasi, seperti adanya fasilitas download dan komunikasi E-mail dalam website pemerintah.

3) Transaction, yang merupakan situs web daerah yang memiliki fasilitas interaksi dan juga dilengkapi dengan fasilitas transaksi pelayanan publik pemerintah.

4) Transformation, dalam hal ini layanan publik meningkat secara terintegrasi.

\section{Indikator Pengembangan e-Government}

Harvard JFK School of Government (Indrajit, 2004), menemukan bahwa dalam menerapkan konsepkonsep digitalisasi di sektor publik maka terdapat tiga elemen kunci kesuksesan yang harus dimiliki dan diperhatikan sungguh-sungguh oleh pemerintah. Elemen-elemen tersebut sebagai berikut:

1) Support

Elemen support adalah elemen paling penting dalam pengembangan e-government perlu dukungan dari pemerintah. Dukungan yang diharapkan adalah bentuk hal-hal sebagai berikut:

a) Adanya political will/ dukungan dari pemerintah yang meliputi kebijakan atau peraturan yang mendukung terlaksananya E-government dan kelembangan yang mengemban tugas untuk mengelola E-gov. Perangkat Hukum merupakan konsep E-government sangat terkait dengan usaha penciptaan dan pendistribusian data/informasi dan hak cipta intelektual, yang perlu dilindungi oleh undang-undang atau peraturan hukum yang berlaku. Dengan adanya perangkat hukum, dapat menjamin terciptanya mekanisme $E$ government yang kondusif. Political will juga untuk meningkatkan akuntabilitas dan transparansi di dalam organisasi.

b) Disosialisasikannya konsep E-gov secara merata, kontinyu, konsisten dan menyeluruh kepada seluruh kalangan birokrat secara khusus dan masyarakat secara umum melalui berbagai cara kampanye yang simpatik. Sosialisasi yang dilakukan untuk memperkenalkan konsep pengembangan E-government tersebut, dengan adanya sosialisasi masyarakat dapat lebih mudah memperoleh informasi dan memahami dengan adanya pentingnya E-government.

c) Adanya kontinyuitas dalam pengembangan $E$-gov. Bagaimana keberlanjutan penerapan $E$ government di pemerintah daerahyang mencakup bagaimana perencanaan E-government ke depannya. Sehingga penerapan good governance dapat tercapai dengan lebih baik, mudah dan lebih cepat.

\section{2) Capacity}

Elemen capacity merupakan sumber daya yang diperlukan dalam pembangunan dan pengembangan $e$-government agar konsep yang telah diciptakan dapat menjadi kenyataan. Terdapat tiga sumber daya yang harus dimiliki, yaitu:

a) Ketersediaan sumber daya finansial yang cukup untuk melaksanakan berbagai inisiatif $e$ government.

b) Ketersediaan infrastruktur teknologi informasi yang memadai karena merupakan $50 \%$ dari kunci keberhasilan penerapan e-government.

c) Ketersediaan sumber daya manusia yang memiliki kemampuan dan keahlian yang dibutuhkan agar penerapan e-government dapat terlaksana dengan baik. 


\section{3) Value}

Elemen value berdasarkan pada manfaat yang didapat oleh pemerintah sebagai pemberi pelayanan dan juga masyarakat sebagai penerima pelayanan e-government. Dalam elemen value yang menentukan besar tidaknya manfaat e-government adalah masyarakat sebagai penerima pelayanan.

\section{METODE PENELITIAN}

Jenis penelitian yang dilakukan adalah kualitatif interpretif. Penelitian kualitatif merupakan penelitian yang didasarkan pada filosofi postpositivisme, yang digunakan dalam meneliti objek yang alamiah, peneliti merupakan sebagai instrumen penting yang menggambarkan konteks penelitian (Sugiono, 2014). Proses penelitian ini secara interaktif dan makna yang tidak terukur oleh data statistik dan bertujuan untuk menggali berbagai informasi secara lebih mendalam serta memungkinkan untuk mendapatkan hal-hal yang tersirat pengumpulan data dilakukan secara triangulasi. Analisis data bersifat induktif dan hasil penelitian kualitatif lebih menekankan makna dari generalisasi. Metode penelitian interpretif ini berupaya merumuskan suatu pertanyaan kemudian dianalisis berdasarkan pada pertanyaan persepsi partisipan yang diteliti.

Penelitian ini dilaksanakan di salah satu instansi pemerintah daerah yang mengelola Website Pemerintah Kabupaten Padang Pariaman yaitu Kantor Dinas Komunikasi dan Informatika Kabupaten Padang Pariaman. Pemilihan tempat penelitian ini sesuai dengan objeknya yaitu pihak yang bertanggungjawab atas pengelolaan website pemerintah daerah dalam pelaksanaan E-government. Serta masyarakat yang bertempat di selingkungan Kabupaten Padang Pariaman.

Jenis data Data primer yaitu dengan melakukan wawancara mendalam dilakukan dengan informan atau narasumber yang memahami konteks masalah yang sedang diteliti. Penelitian ini menggunakan data yang diperoleh melalui wawancara semi-struktur yang dipandu dengan interview guide dengan pejabat Dinas Komunikasi dan Informatika Kabupaten Padang Pariaman. Data sekunder merupakan data yang didapatkan secara tidak langsung melalui perantara yang diperoleh dari pihak ketiga seperti literatur, tulisan, dokumentasi, tulisan sebagai perbandingan dari data yang diperoleh seperti buku referensi, surat kabar atau media elektronik seperti website pemerintah daerah.

Dalam rangka mengumpulkan data dan informasi yang valid dan akurat, peneliti akan melakukan wawancara. Wawancara yang dilakukan oleh peneliti dibantu dengan alat perekam. Alat perekam ini digunakan untuk bahan cross check bila pada saat analisa terdapat data, keterangan atau informasi yang tidak sempat dicatat oleh peneliti. Dalam penelitian ini peneliti menggunakan empat teknik pengumpulan data yaitu wawancara semi struktur, triangulasi, observasi langsung dan analisis dokumen.

Analisis data merupakan proses sistematis untuk meneliti dan mengumpulkan data yang diperoleh dari hasil wawancara, catatan lapangan, dan bahan-bahan lainnya sehingga mudah dipahami, dan temuannya dapat diinformasikan kepada orang lain (Sugiyono, 2014). Pada penelitian ini tahap-tahap analisis data dilakukan untuk menentukan kategori, konsep, tema dan pola dan terakhir melakukan analisis data. Langkah-langkah dalam menganalisis data yaitu: 1. Data dikumpulkan dengan menggunakan wawancara semi terstuktur, 2. Pada saat wawancara peneliti sudah melakukan analisis terhadap jawaban wawancara, 3. Wawancara direkam dengan alat bantuan panduan wawancara, 4. Selama pengumpulan data peneliti mengolah catatan lapangan dan hasil wawancara dengan berusaha untuk tidak mendistorsikan makna dari tanggapan narasumber selama proses pengumpulan data, 5. Hasil transkip wawancara dikaitkan dengan theorical framework yang ada sehingga tidak bersifat bias tetapi dapat dijelaskan oleh 
teori tersebut, 6. Analisis wawancara melalui proses coding, 7. Klasifikasi data wawancara disesuaikan dengan tema dan kerangka konseptual yang ada dalam penelitian untuk memastikan konsistensi wawancara.

\section{HASIL DAN PEMBAHASAN}

Penelitian yang dikaji peneliti berkenaan dengan Analisis Pengembangan Electronic Government melalui Penyelenggaran Website di Pemerintahan Kabupaten Padang Pariaman. Data hasil penelitian yang berhasil dikumpulkan dari beberapa pihak terkait yang terjadi di lapangan dan menanyakan kepada pihak terkait dengan pengembangan e-government dalam Dinas Kominfo serta respon mereka dalam menyikapi pertanyaan terbuka yang diberikan oleh peneliti.

\section{Sejarah Penerapan E-government}

Berawal dari reformasi politik tahun 1998, Indonesia muIai memperbaiki sistem birokrasi administrasi publik yang salah satunya adalah dengan adanya sistem e-government. Egovernment mulai diadaptasi kepada pemerintah ditandai dengan adanya Inpres Nomor 6 Tahun 2001 yang mendorong penggunaan teknologi telematika guna mewujudkan terciptanya good governance serta mengakselerasi terwujudnya demokrasi yang dicita-citakan. Aturan tersebut kemudian diganti dengan Inpres Nomor 3 tahun 2003. Inpres ini berisi tentang Kebijakan dan Strategi Pengembangan E-gov. Berdasarkan aturan tersebut, Presiden RI dengan tegas memerintahkan kepada pemerintah daerah baik kota maupun kabupaten untuk menerapkan $E$ government dengan langsung melakukan koordinasi dengan Menteri Komunikasi \& Informasi.

Proses implementasi di daerah merupakan tekanan yang diberikan oleh pemerintah pusat. Pemerintah daerah sebenarnya tidak memiliki pilihan lain selain menerapkannya. Salah satu pemerintah daerah yang telah menerapkannya adalah pemerintah Kabupaten Padang Pariaman. E-gov mulai diterapkan di Kabupaten sejak tahun 2014 di bawah naungan humas pemerintah daerah namun sejak tahun 2016 kemudian dikelola oleh Dinas Kominfo. Hal ini terbukti dengan adanya situs web pemerintah daerah Kabupaten Padang Pariaman.

Berikut kutipan yang diungkapkan oleh salah satu informan:

"kabupaten Padang Pariaman sendiri sudah lama melaksanakan e-gov. Pemerintah telah menerapkan e-gov sejak tahun 2014 dengan dibuatnya website pemerintah dan yang mengelolanya itu langsung kami Dinas Komunikasi dan Informatika (Diskominfo) Kabupaten Padang Pariaman itu sesuai dengan aturan yang sudah ada." (Bpk. D, Kepala Bidang e-government)

Hal ini juga dinyatakan oleh informan lain:

"kita wajib untuk menerapkannya sesuai dengan aturan. Semuanya kita seluruh kabupaten/kota kan wajib untuk menerapkannya. Kita sudah menerapkannya itu pada tahun 2014. Awalnya kita hanya membuat website saja, namun sekarang sudah banyak program e-gov yang akan kita jalankan. Itu sesuai dengan apa yang ingin dicapai pemerintah." (Bpk. H, Kasi Pengembangan Ekosistem $e$ government)

Berdasarkan jawaban informan tentang sejarah awal penerapan e-gov, tidak ada sebenarnya alasan lain untuk menerapkan e-gov selain kepada tuntutan dari aturan. Dapat disimpulkan bahwa penelitian ini mendukung penelitian dari Yunita dan Aprianto:2018; 
Nugraha: 2018 bahwa implementasi e-gov di daerah karena dipengaruhi oleh adanya tekanan hukum/regulasi.

\section{Pengembangan E-gov yang Dilakukan Pemda.}

Pengembangan e-gov merupakan bagaimana upaya yang dilakukan pemerintah dalam keberlanjutan penerapan e-gov di Kabupaten Padang Pariaman dimulai dari fase perencanaan hingga pada fase pematangan e-gov di Kabupaten Padang Pariaman. Pengembangan kedepannya yang dilakukan pemerintah daerah Kabupaten Padang Pariaman adalah berfokus pada pengintegrasian seluruh OPD yang ada di Kabupaten Padang Pariaman. Dengan adanya hal itu, berbagai informasi dapat terkoordinasi ke dalam satu server dengan perantara Dinas Komunikasi dan Informatika.

Hal ini sesuai dengan pernyataan dari salah satu informan sebagai berikut: "kalau kedepannya kita sudah mempersiapkan beberapa rencana dalam pengembangan e-gov. Hal ini sesuai dengan rencana strategis OPD kita. Kedepannya kita berencana membuat sebuah server seperti portal. Portal ini berfungsi agar semua informasi dan penyebaran data dapat lebih terkoordinasi antar OPD yang ada. Tidak seperti dulu, membutuhkan waktu dan proses yang lama. Dengan adanya portal masyarakat dapat dengan mudah memperoleh informasi tanpa harus datang ke kantor." (Ibu K, Kasi Pelayanan Informasi Publik)

Pengembangan TIK sampai saat ini bisa dikatakan belum cukup baik. Hal ini dikarenakan belum terkoordinasi dan terintegrasinya antar sistem informasi. Tidak hanya pengembangan di teknologi saja, untuk menyukseskan e-gov ini pemerintah juga berupaya untuk mengembangkan sistem informasi.

Hal ini sesuai dengan pernyataan dari informan lainnya:

"sekarang ini pemerintah sedang giat-giatnya dalam penerapan e-gov hingga ke setiap OPD yang ada. Untuk itu, fokus kita sekarang yaitu pada pengembangan sistem. Karena sistem informasi masih belum terkoordinasi dengan baik. Selama ini sistem informasi yang ada dulu masih pada masing-masing OPD dan OPD lain tidak bisa memperoleh informasi. Maka pemerintah berupaya agar informasi dapat diperoleh dengan cepat dan mudah. Misalkan pada Badan Keuangan Pemerintah Daerah yang membutuhkan data pegawai untuk mengelola sistem pengelolaan gaji dengan memakai data-data kepegawaian pemerintah yang diambil dari Badan kepegawaian aerah pemerintah. Rencana kedepannya agar sistem informasi dapat lebih baik dan juga untuk memenuhi kepentingan masingmasing OPD. Apabila sistem kita sudah terkoordinasi dan terintegrasi dengan baik, penyebaran informasi dapat lebih mudah dan transparan.” (Bpk. RS, Kabid Teknologi, Informasi dan Komunikasi)

Fokus kedepannya yang akan dilakukan adalah untuk pengembangan smart city. Pemkab Padang Pariaman merupakan salah satu kabupaten terpilih sebagai percontohan daerah yang menerapkan smart city. Pemerintah serius dalam menerapkannya bertujuan untuk memperbaiki layanan publik salah satunya dengan cara pengembangan infrastruktur untuk mendukung 
adanya smart city.

Berikut kutipan dari seorang informan:

"Tahapan selanjutnya bagi kita itu adalah pengembangan smart city, kita kan termasuk salah satu daerah yang ikut dalam proyek pelaksanaan smart city. Oleh sebab itu, penerapan smart city akan terlaksana jika didukung juga dengan adanya infrastruktur. Misalnya itu seperti dengan menambah jaringan, memperbaiki sistem serta memperluas jangkauan internet hingga ke seluruh daerah pelosok di kabupaten padang pariaman. Pemerintah Kab. Padang Pariaman berupaya keras agar hal ini tercapai terutama dalam hal pengembangan infrastruktur." (Bpk. BY. R, Kepala Bidang Informasi dan Komunikasi Publik)

Berdasarkan hasil wawancara, perencanaan pengembangan sudah dilakukan namun pelaksanaannya yang sulit. Pemerintah daerah baik pusat maupun tingkat daerah wajib untuk menyelenggarakan e-government sesuai dengan instruksi dari undang-undang. Pelaksanaannya sendiri untuk kabupaten Padang Pariaman menurut sebagian besar informan mengatakan bahwa pengembangan $e$-gov sudah cukup baik namun masih belum optimal.

Hal ini sesuai dengan penyataan beberapa orang informan:

"sampai sejauh ini sih sudah cukup baik, kita sedang gencar-gencar untuk menerapkan e-gov terutama di semua OPD. ”...

.... "sebenarnya kalau bagi bapak ya, penerapan e-gov di Padang Pariaman masih belum optimal.” (Bpk. H, Kasi Pengembangan E-government)

Hal ini ditegaskan kembali oleh informan lainnya:

" masalah kita ya itu, penerapan e-gov di sini belum merata. Hanya beberapa

OPD saja yang mau ikut serta dan berperan aktif." (Ibu K, Kasi Pelayanan Informasi Publik)

Ada hal yang menarik untuk dibahas mengenai kata-kata "belum optimal". Kita tidak tahu berapa ukuran yang pasti untuk kata-kata "optimal". Bisa saja penerapannya sudah mencapai 80 $\%$, bisa juga berkisar 50\% sampai $70 \%$, atau bahkan masih di bawah 50\%, namun salah seorang informan memberikan pernyataan terkait masalah ini:

"menurut bapak sih, pengembangan e-gov udah mencapai 60\%. Hal itu sesuai dengan RJMD yang sudah kita buat. Penerapan kita." (Bpk. D, Kabid Layanan Egovernment)

Hal ini ditegaskan kembali dengan informan lainnya

"Penerapan e-gov di daerah masih belum maksimal terutama di Padang Pariaman, ada berbagai kendala yang kita hadapi. kalau di tanya persentase keberhasilan pemda itu kisaran 50 atau $60 \%$ deh." (Bpk. RS, Kabid Teknologi, Informasi dan Komunikasi) 
Berdasarkan pernyataan tersebut bahwa penerapan e-gov di Kabupaten Padang Pariaman masih berkisar antara 60\%. Sistem ini diperkenalkan sejak tahun 2003 dan Padang Pariaman sudah melaksanakan sejak tahun 2014. Lima tahun berlalu dan nilai yang didapat masih berkisar pada angka 60. Dapat disimpulkan bahwa penerapan, dalam hal ini pelaksanaan e-government di Kabupaten Padang Pariaman sendiri masih belum optimal. Hal ini sesuai dengan Sosiawan: 2008; Ordiyasa: 2015; Kumorotomo: 2009; Sari dan Winarno: 2012 bahwa sampai saat ini penerapan e-government masih belum optimal.

\section{Kendala dalam Pengembangan E-government \\ Support}

Belum Kuatnya Political Will. Adanya unsur political will merupakan bukti keseriusan atau komitmen pemerintah di dalam penerapan e-gov. Hal itu terbukti dimana pemerintah mengeluarkan Peraturan Bupati No. 40 Tahun 2019 Tentang Penyelenggaraan dan Pengembangan e-government yang menyatakan bahwa dalam rangka untuk mendukung penyelenggaraan pelayanan publik untuk melaksanakan urusan wajib pemerintahan dalam bidang komunikasi dan informasi, maka peraturan tentang Penyelenggaraan e-government sebagai langkah implementasi birokrasi. Adanya regulasi ini bertujuan untuk mendorong dan mempercepat Organisasi Perangkat Daerah (OPD) untuk menerapkan Sistem Pemerintahan Berbasiskan Eletronik (SPBE).

Peraturan daerah tersebut masih dikatakan baru dan pada kenyataannya penerapan $e$ government di Kabupaten Padang Pariaman masih kurang maksimal, karena kurangnya pengetahuan serta manfaat akan adanya e-government di tiap OPD.

Hal ini sesuai dengan yang diungkapkan oleh seorang informan:

"Kalau payung hukum mengenai e-gov kita sudah punya peraturan daerah sejak tahun 2019 yang mengatur pengelolaan e- Gov di Kabupaten Padang Pariaman. Namun peraturan daerah itu belum sepenuhnya diterapkan ke seluruh OPD yang ada di Kabupaten Padang Pariaman. Kalau terkait dengan adanya masterplan, kita masih dalam proses penyusunannya. Saat ini, kita masih berpedoman dengan RJMD saja." (Bpk. BY. R, Kepala Bidang Informasi dan Komunikasi Publik)

Hal senada disampaikan oleh informan lainnya:

"kita sudah punya aturan terkait dengan penerapan e-gov. Aturan tersebut baru dibentuk dan efektif tahun 2019. Aturan ini dibentuk agar setiap OPD dapat berpedoman dalam menggunakan sistem berbasis elektronik terutama dalam penggunaan website. Peraturan Bupati kita sudah ada namun belum sampai ke Peraturan Daerah. Kita belum memiliki rencana induk (masterplan) kegiatan kita dalam pengembangan e-gov. Namun saat ini, pemkab sedang berfokus dalam pembahasan rencana masterplan." (Ibu K, Kasi Pelayanan Informasi Publik)

Berdasarkan hasil wawancara dapat diketahui meskipun adanya regulasi tidak juga menyadarkan setiap OPD tentangnya penerapan e-gov karena masih banyak OPD yang masih pasif. Pemerintah harus memiliki regulasi yang kuat dan isinya harus lebih mendetail terkait dengan pengaplikasian e-gov. Indrajit (2006) mengemukan bahwa political will merupakan hal utama yang harus ada di dalam kerangka perencanaan dan pengembangan $e$-government.

Hal ini sejalan dengan penelitian Lestari:2018 ; Arif dkk:2013, bahwa kesuksesan $e$ - 
government di pemerintah daerah dipengaruhi dengan adanya hukum/regulasi yang kuat. Ramon dan Pardo (2005) menyebutkan bahwa peraturan yang ketat akan mempengaruhi keberhasilan penerapan e-gov. Pemerintah harus memiliki perangkat hukum yang dapat menjamin terciptanya mekanis e-government yang kondusif dan juga bertujuan untuk memperbaiki sistem administrasi yang ada sehingga dapat mewujudkan tata pemerintah yang baik (good governance).

Kurangnya Sosialisasi. Sosialisasi merupakan sarana penting bagi pemerintah untuk mendukung kesuksesan penerapan e-gov di daerah. Dimana dengan adanya sosialisasi ini masyarakat dapat mengetahui adanya informasi terkait adanya e-gov serta ikut serta dalam membangun $e-G o v$ tersebut. Pemerintah daerah sudah melakukan sosialisasi website resmi dengan alamat domain yakni www.padangpariamankab.go.id. Sosialisasi yang dilakukan hanya satu arah dan hanya melalui medsos saja seperti menggunakan facebook, twitter, dan instagram. Hasil dari pengamatan peneliti bahwa pemerintah kurang melakukan sosialisasi terutama sosialisasi secara langsung.

Berikut adalah beberapa petikan ungkapan informan:

"untuk sosialisasi secara langsung belum pernah sih. Karena kita kan organisasi vertikal yang berfungsi untuk membantu setiap OPD untuk menyebarkan informasi kepada masyarakat. Biasanya yang melakukan sosialisasi secara langsung itu masing-masing OPD. Kita biasanya melakukan sosialisasi hanya lewat medsos seperti facebook, twitter, dan instagram. Menurut anjuran dari Pak Bupati Padang Pariaman Pak Ali Mukhni setiap OPD harus mempunyai media sosial sebagai media interaksi pemerintah dengan masyarakat. Selain media elektronik, kita juga melakukan sosialisasi dengan media cetak, seperti koran terkait dengan berita dan kegiatan pemerintah.” (Bpk.BY. R, Kabid Informasi dan Komunikasi Publik)

"kita sih biasanya melakukan sosialisasi melalui media sosial aja. Sosialisasi dilakukan melalui facebook, twitter dan instagram." (Bpk, RS Kepala Bidang Teknologi, Informasi dan Komunikasi)

"kalau sosialisasi secara langsung ke masyarakat gak pernah, karena sepengetahuan bapak sih untuk sosialasi langsung itu OPD nya. Misalnya itu Dinas kependudukan dan Catatan Sipil biasanya mereka lakukan sosialisasi ke setiap nagari-nagari. terkait dengan Sosialisasi dilakukan melalui media sosial seperti facebook, twitter dan instagram." (Bpk. Ro, Kasi Pengembangan Infrastruktur)

Berdasarkan hasil wawancara dapat diketahui bahwa kurangnya sosialisasi yang dilakukan pemerintah kabupaten Padang Pariaman kepada masyarakat. Hal ini sesuai dengan hasil observasi peneliti, banyak masyarakat sebagai pengguna website yang belum mengetahui dan menikmati layanan ini. Temuan ini sesuai dengan penelitian yang dilakukan oleh Irawan (2017) bawa sosialisasi kepada masyarakat memiliki peran penting dalam menyukseskan e-gov. Sebab dengan adanya sosialisasi, masyarakat akan mengetahui keberadaan website dan penggunaan $e$ government tersebut. 


\section{Capacity}

Ketersediaan Sumber Daya Finansial. Ketersediaan sumber daya finansial yang cukup merupakan penunjang pelaksanaaan e-gov di suatu daerah, salah satunya berkaitan dengan sumber daya finansial. Sekecil apapun inisiatif e-government yang akan diterapkan membutuhkan sejumlah sumber daya yang sangat besar. Dalam menerapakan e-Gov, pemerintah daerah kabupaten Padang Pariaman memperoleh sumber pendanaan berasal dari Anggaran Pendapatan Belanja Daerah (APBD) Kabupaten Padang Pariaman. Pemerintah merancang semua kegiatan berdasarkan rencana strategis yang sudah diterapkan sebelumnya.

Berikut petikan dari salah satu informan:

"kalau sumber dana finansial kita itu berasal dari APBD Kabupaten Padang Pariaman. Biasanya setiap tahun kita mengajukan anggaran untuk kegiatan tahun berikutnya. Pengajuan sendiri itu berdasarkan rencana strategis OPD, misalnya seperti kita Dinas Kominfo, kita harus menyusun terlebih dahulu di rencana strategi kemudian mengajukan ke tim anggaram untuk kegiatan yang kita lakukan.” (Ibu K, Kasi Pelayanan Informasi Publik)

Anggaran dalam penerapan e-gov dirasakan masih kurang. Diskominfo merasa kesulitan dalam pengembangan $e$-gov disebabkan karena anggaran yang masih minim. Terutama dengan upaya pemerintah dalam melaksanakan smartcity kedepannya haruslah membutuhkan biaya yang begitu besar.

Berikut petikan yang diungkapkan dari informan lainnya:

"kalau masalah dana ini sangat sensitif untuk dibicarakan. Menurut bapak, Anggaran Diskominfo untuk media massa terutama dalam hal pengembangan egov dan terkait dengan masih minim. Karena sulit sekali agar e-gov tercapai dengan baik terutama dalam hal infrastruktur dan sumber daya manusia kita." (Bpk. Ro, Kasi Pengembangan Infrastruktur)

Berdasarkan hasil wawancara dapat diketahui anggaran merupakan permalasahan serius bagi pemerintah daerah. Hal ini relevan dengan penelitian yang dilakukan oleh Sosiawan: 2008; Ordiyasa: 2015 bahwa anggaran merupakan hal yang penting dalam pengembangan $e$ government. Kegagalan e-government di Indonesia salah satunya karena terkendala di anggaran. Anggaran menjadi masalah serius bagi pemerintah dalam penerapan $e$-gov.

Belum Optimalnya Infrastuktur. Dalam pelaksanaan e-government, ketersediaan infrastruktur telekomunikasi perangkat keras seperti komputer, jaringan dan infrastruktur lainnya merupakan faktor teramat penting dalam penerapan e-government. Namun berdasarkan kenyataannya, sarana dan prasarana masih belum memadai dalam menunjang penerapan $e-G o v$ di Kabupaten Padang Pariaman, seperti kurangnya ketersediaan gedung, peralatan dan server belum ada.

Hal ini sesuai dengan pernyataan seorang informan:

"nah, kalau ditanya apa kendala kita ya salah satunya kurangnya sarana dan prasarana dalam menunjang penerapan e-gov terutama infrastruktur gedung kominfo masih kayak gini, kita tergabung dengan beberapa dinas dan OPD. Jadi 
kesulitan bagi kita terutama ketersediaan ruangan. Infrastruktur kantor saja belum lengkap / belum tersedia. Misalnya kita masih kekurangan server untuk menghubungkan antar OPD dan antar instansi yang ada di Kabupaten Padang Pariaman. Sebenarnya kita sudah memasukan perencanaan terkait dalam pengadaan infrastruktur dan peralatan. Insha Allah tahun 2020 kita ingin menambah beberapa server ke depannya dan menambahkan beberapa jaringan hingga ke seluruh daerah di Kabupaten Padang Pariaman." (Bpk Ro, Kasi Pengembangan Infrastruktur Jaringan)

Hal senada disampaikan oleh informan lainnya:

"Untuk saat ini sarana dan prasarana belum memadai karena ada beberapa alat seperti kita masih kekurangan komputer dan alat elektronik lainnya. Kita masih dinas baru, jadi kita belum semuanya optimal sarana untuk bekerja, karena kekurangan dengan hal itu, pegawai juga menggunakan laptop pribadi mereka." (Bpk. BY.R, Kabid Teknologi, Informasi dan Komunikasi)

Kurangnya sarana dan prasarana dinas komunikasi dan Informatika, mengakibatkan kesulitan untuk meningkatkan kualitas pegawai terutama ahli IT. Berikut kutipan dari seorang informan:

"Kita mengalami kesulitan dalam meningkatkan kualitas para pegawai terutama yang paham dengan IT dan programmer. Salah satnya karena kita kekurangan peralatan yang mendukung seperti computer, ruangan untuk lab computer dan lainnya." (Bpk. H, Kasi Pengembangan Ekosistem E-Gov)

Selain itu, di Dinas Komunikasi dan Informatika belum mempunyai lab komputer, sehingga masih kesulitan dalam meningkatkan kualitas prakom. Berikut kutipan dari seorang informan:

"Sarana dan prasarana belum menunjang terutama gedung maupun peralatan lainnya, misalnya kita belum punya lab komputer. Kita mau meningkatkan kualitas para prakom itu kesulitan. Kita mau mengumpulkan banyak orang dengan adanya komputer banyak disatu lokasi itu tidak ada tempat.” (Bpk. H, Kasi Pengembangan Ekosistem E-Gov)

Keberhasilan e-gov juga dipengaruhi terpenuhi atau tidaknya infrastruktur. Banyak penerapan e-gov gagal karena kurang memadainya infrastruktur. Indrajit (2004) mengungkapkan bahwa ketersediaan infrastruktur teknologi informasi merupakan 50\% dari kunci keberhasilan pengembangan konsep Electronic Government. Artinya ketersediaan infrastruktur tekonologi sangat berpengaruh dalam kesuksesan pengembangan Electronic Government. Berdasarkan hasil wawancara diketahui pemerintah masih kendala dalam penerapan e-gov karena kurangnya infrastruktur. Temuan ini sesuai dengan hasil penelitian yang diungkapkan oleh Habibullah: 2010; Ordiyasa: 2015; Retnowati \& Retnowati: 2008 bahwa masalah infrastruktur berpengaruh besar dalam penerapan e-gov di daerah.

Kurangnya Sumber Daya Manusia (SDM). Sumber daya manusia merupakan pemain utama atau subyek yang berperan penting dalam penerapan e-government. Sumber daya manusia pada dasarnya merupakan manusia yang bekerja di pemerintahan, sehingga tingkat kompetensi dan keahlian dari SDM akan sangat berpengaruh besar pada performa penerapan e-government. 
Pemerintah Kabupaten Padang Pariaman terkait pengembangan dan penempatan SDM TIK belum direncanakan dengan baik, sehingga banyak pegawai yang bekerja tidak selaras dengan keahliannya.

Hal ini sesuai dengan pernyataan dari seorang informan:

"kalau terkait dengan SDM, kita masih kekurangan, terutama pegawai yang mengelola TI masih kurang. Pegawai yang paham terkait dengan programmer dan paham TI diskominfo baru ada 6 orang. Jadi hanya 6 orang yang mengelola seKabupaten Padang Pariaman sehingga tidak bisa optimal, sedangkan projek atau tugas diskominfo begitu besar jadi menurut bapak perlu ditambahin pegawai yang paham TI. Kita sudah mengajukan permintaan kepada Badan Kepegawaian terkait rekruitmen pegawai, selain itu juga kami juga membuka lowongan yang nonPNS.” (Bpk. D, Kabid Layanan E-government)

Hal yang sama disampaikan oleh informan lainnya:

"Diskominfo sendiri masih kekurangan pegawai terutama yang bagian TI. Sampai sekarang sih, diskominfo sendiri baru mempunyai 6 prakom, sehingga hal itu menyulitkan kami untuk bekerja lebih optimal.” (Bpk. R, Kabid Teknologi, Informasi dan Komunikasi)

"Pegawai kita di sini 25 orang, dan hanya beberapa orang yang paham tentang TI. Karena tidak semua pegawai yang keahliannya sesuai dengan pekerjaannya. Misalnya saja bapak sendiri, bapak saja lulusan administrasi publik sedangkan bapak ditempatkan di bidang e-gov yang berkaitan dengan programmer. Tidak bapak saja, karena kebanyakan pegawai di sini di ambil dari beberapa OPD. Salah satu permasalahan kita juga karena di sini masih sedikit pegawai yang muda. Kalau yang tua begini gak paham tentang TI begituan." (Bpk. BY R, Kabid Informasi dan Komunikasi Publik)

Pemberian pelatihan kepada pegawai merupakan faktor penting dalam meningkatkan kemampuan pegawai. Dengan adanya pelatihan kepada pegawai terutama di bidang TI dapat menunjang kesuksesan penerapan e-gov. Pelatihan kepada pegawai tidak rutin dilakukan disebabkan karena anggaran yang minim.

Berikut kutipan ungkapan dari seorang informan:

"kalau pelatihan ada, namun tidak rutin dilakukan. Biasanya pelatihan pegawai bagi diskominfo sendiri diadakan oleh Badan Kepegawaian dan Pengembangan Sumber Daya manusia. Sedangkan pelatihan kepada pranata computer yang ada di Kabupaten Padang Pariaman. Pelatihan agar OPD dapat lebih paham tentang e-gov. Prakom yang ada di Kabupaten Padang Pariaman itu lebih dari 60 orang. Jadi hanya beberapa prakom yang bisa diikutkan pelatihan. Karena untuk melakukan pelatihan membutuhkan dana yang cukup besar sedangkan kita keterbatasan mengenai anggaran dan tempat, sehingga yang mengikuti pelatihan hanya beberapa orang. Hanya beberapa pegawai kominfo yang bisa diikutkan."

(Ibu K, Kasi Pelayanan Informasi Publik) 
Berbagai upaya telah dilakukan dalam menangani kendala ini seperti dengan lebih memperbanyak pelatihan kepada pegawai. Salah satu caranya dengan meningkatkan anggaran untuk sosialisasi pegawai serta dan direncanakan dalam rencana strategis Dinas Kominfo untuk pengembangan SDM seperti melakukan pelatihan, diklat, dan lainnya.

Hal ini sesuai dengan yang diungkapkan oleh seorang informan:

"untuk meningkatkan kualitas pegawai biasanya kita melakukan pelatihan. Salah satu unsur penting mendukung e-gov adalah SDM, SDM kan harus ada pelatihannya, kita masukan di renstra agar diupayakan ada dana untuk pengembangan SDM misal buat latihan, diklat, khursus dll.” (Bpk. BY. R, Kabid Informasi dan Komunikasi Publik)

Kemampuan pegawai dalam menggunakan teknologi informasi merupakan hal penting dan perlu ditingkatkan untuk menyukseskan pelaksanaan e-government di Kabupaten Padang Pariaman. Hal yang kurang saat ini yaitu pegawai yang paham menggunakan sistem elektronik.

Hal yang sama diungkapkan oleh seorang informan:

...... "Kemampuan pegawai kalau masih dibilang masih ada ketimpangan, karena ada yang sebagian sudah bisa, dan sebagian yang lain belum paham. Akibatnya hanya beberapa pegawai yang paham tentang e-gov terutama dalam pelaksanaan website. Setiap OPD diharapkan memiliki website sehingga kadang kita tidak dapat memenuhi kebutuhan setiap OPD. Diskominfo masih kekurangan tenaga pranata computer yang bertugas untuk pengelolaan TI di kabupaten. Kadang tugas-tugas kita terbengkalai, karena masalah ini. Sehingga diperlukan adanya pelatihan bagi SDM." (Bpk. D, Kepala Bidang E-Government)

Berdasarkan hasil wawancara, ketersediaan sumber daya manusia (SDM) masih kurang, dan pegawai yang bekerja tidak sesuai dengan kebutuhan pekerjaan yang tersedia. Sehingga hanya beberapa pegawai saja yang dapat menggunakan teknologi informasi. Pelatihan kepada pegawai tidak rutin dilakukan dan hanya beberapa orang yang bisa mengikuti pelatihan. Hanya beberapa pegawai Dinas Komunikasi dan Informatika yang bisa diikutkan karena adanya keterbatasan anggaran.

Kualitas Sumber Daya Manusia menjadi masalah serius dalam penerapan e-government. Indrajit (2004) mengemukakan bahwa semakin tinggi tingkat information technology literacy SDM menunjukkan pemerintah semakin siap dalam menyukseskan e-government. Temuan ini sesuai dengan hasil penelitian yang diungkapkan oleh Irawan: 2015; Retnowati: 2008 bahwa masalah SDM berperan penting dalam penerapan e-gov, khususnya di pemerintah daerah. Kurangnya sumber daya manusia baik dari segi kualitas dan kuantitas sangat mempengaruhi $e$ government di Pemerintah Daerah Kabupaten Padang Pariaman.

\section{Manfaat (Value) Penerapan E-Government}

Selain dengan kedua elemen itu, e-gov juga memberikan manfaat yang besar bagi pemerintah daerah. E-government memberikan manfaat terkhususnya bagi Pemerintah Kabupaten Padang Pariaman. Ada beberapa manfaat dengan adanya website resmi Pemerintah Kabupaten Padang Pariaman. 
Berikut petikan yang diungkapkan informan terkait manfaat e-government:

"sejauh ini sih, penerapan e-government sangat membantu kami, terutama dalam hal penyebaran informasi dan pelayanan kepada masyarakat. Dengan adanya website ini, pelayanan dapat lebih cepat, dimana yang dulunya membutuhkan waktu yang lama. Banyak keuntungan yang dirasakan dengan adanya website, tidak hanya pemerintahan tapi juga semua pihak yang ada seperti pihak swasta, calon investor, dan stakeholder lainnya."(Bpk. H, Kasi Pengembangan Ekosistem E-gov)

Hal yang sama disampaikan oleh informan lainnya:

"ada dampak positif diterapkannnya sistem e-government salah satunya itu masyarakat dapat menerima laporan kinerja pemerintah secara aktual dan transparan, masyarakat juga bisa dengan leluasa mengakses informasi seputar kinerja pemerintah. Selain itu sistem e-government juga dapat menekan anggaran biaya. Dengan teknologi online, pekerjaan juga tentunya akan lebih efesien, secara biaya dan waktu." (Bpk. RS, Kabid Teknologi, Informasi dan Komunikasi)

Implementasi e-government di sektor publik merupakan suatu keharusan bagi setiap pemerintah. E-gov memberikan manfaat terutama dalam pelayanan publik kepada masyarakat.

Hal ini sesuai dengan pernyataan dari seorang informan, beliau menjelaskan: "kalau menurut bapak ya, e-gov sangat berperan penting untuk penyebaran informasi dari pemerintah kepada masyarakat. Pelayanan publik dapat lebih cepat dan efektif. Masyarakat juga dengan mudah berinteraksi dan mendapatkan informasi. Tidak hanya itu, e-gov juga merupakan alat yang baik guna untuk mewujudkan good governance." (Bapak Ro, Kasi Pengembangan Infrastruktur)

Berdasarkan hasil wawancara dapat diketahui ada beberapa manfaat adanya e-gov bagi pemerintah adalah meningkatkan transparansi pemerintah kepada masyarakat dengan publikasi melalui website seperti mempublikasikan berita kegiatan pemerintahan maupun publikasi laporan-laporan keuangan. Selain itu e-gov bermanfaat untuk meningkatkan layanan publik dan juga berguna untuk mewujudkan good governance.

Temuan ini sesuai dengan penelitian yang dilakukan Cynthia dkk: 2015; Arif dkk: 2013; Puspa dan Hariani: 2017; Risnandar: 2019 terdapat manfaat yang signifikan dengan diterapkannya penerapan e-government, diantaranya meningkatkan transparansi, meningkatkan Pelayanan publik kepada masyarakat serta mewujudkan good governance.

\section{Tanggapan Masyarakat Terkait Penerapan E-Gov}

Manfaat diterapkannya E-gov bagi Stakeholders. Penerapan e-gov tidak akan ada gunanya jika tidak ada pihak yang merasa diuntungkan dengan adanya implementasi konsep tersebut. Yang menentukan kesuksesan e-gov adalah seberapa besar e-gov memberikan manfaat yang diperoleh dengan adanya e-government. Manfaat di sini bukan hanya bagi pemerintah daerah sendiri, melainkan juga kepada masyarakat dan pihak yang berkepentingan (stakeholders). 
Berikut kutipan informan terkait manfaat $e$-gov bagi mereka, sebagai berikut:

"Adanya e-gov ini, menurut bapak cukup bermanfaat. Karena bapak pernah membuka website Disdukcapil, di situ udah dijelaskan program-programnya seperti pembuatan akte kelahiran dan kartu tanda penduduk elektronik. Di situ juga di jelasin pelayanan-pelayanannya di daerah Kabupaten padang pariaman. Contohnya saja ada program pesan antrian lewat sms. Jadi kita gak perlu pagipagi antri ke sana.” (Bpk. E, Karyawan Swasta 30 tahun)

"kalau bagi ibuk, itu sangat bermanfaat terutama bagi kami para guru. Karena dengan adanya website, kami dapa melihat informasi mengenai kegiatan pemerintahan terutama di OPD Dinas Pendidikan. Website juga menampilkan beberapa informasi penting tentang tenaga pendidik serta regulasi hukum terkait dengan pelatihan kepada guru." (Ibu S, Guru 29 tahun)

"ketika saya mengurus izin usaha saya, saya sama sekali tidak mengetahui apa itu layanan e-government. Dulu kalau mengurus surat izin membutuhkan waktu yang lama berbeda dengan sekarang semua serba cepat, sekarang sudah bisa lewat internet saja, gak perlu lama-lama. Kita juga sudah tahu apa saja syaratsyaratnya." (Ibu N, Pengusaha 35 tahun)

"Cukup bermanfaat, saat saya mengurus izin usaha saya, saya membuka website Pemerintah Padang Pariaman, disitu sudah ada link ke Dinas Penanaman Modal Pelayanan Terpadu. Dengan adaanya sistem online, kita hanya langsung masukin data dan urus nya secara langsung. Kalau dulu kita harus datang ke kantor, sekarang di rumah saja kita sudah bisa. Itu saja sudah mengemat waktu, dan juga menghemat biaya." (Ibu L, Pengusaha 45 tahun)

"e-gov kalau menurut saya sih memberikan manfaat yang baik bagi masyarakat terutama mencari informasi-informasi tentang pemerintah daerah misalnya mau melihat laporan keuangan ataupun berita-berita daerah padang pariaman." (Bpk. $\mathrm{R}$, pegawai dinas)

Berdasarkan hasil wawancara dapat diketahui manfaat e-gov bagi masyarakat adalah memudahkan masyarakat dalam mencari segala informasi yang dibutuhkan. Temuan ini sesuai dengan hasil penelitian Nugraha: 2018; Rahman:2011 bahwa dengan e-government pelayanan terhadap stakeholders (masyarakat, pengusaha dan lainnya) dapat lebih efisien dan efektif dan manfaatnya adalah transparansi dari pemerintah. Informan-informan tersebut mendapat informasi mengenai biaya yang harus dikeluarkan, langkah-langkah prosedur yang dijalani dan waktu yang dibutuhkan untuk menyelesaikan izin.

Kendala yang Dirasakan Masyarakat. Implementasi e-government di Pemerintah Kabupaten Padang Pariaman masih belum optimal. Hal ini disebabkan oleh beberapa faktor tidak hanya internal namun juga kendala eksternal yaitu masyarakat sebagai pengguna layanan fasilitas e-gov. Masyarakat Kabupaten Padang Pariaman belum sepenuhnya bisa menggunakan internet atau melek teknologi. Hal ini disebabkan karena budaya masyarakat yang masih belum mau menggunakan teknologi. 
Marzeti (Petani, 40 tahun)

"Saya tidak begitu paham menggunakan komputer, apalagi internet mbak. Saya gak pernah buka internet, tidak paham yang begituan."

Syamsurizal (Wiraswasta, 42 tahun)

"Saya gak pernah pake internet dek, hp saya saja masih jadul cuma bisa buat sms sama nelpon, gak mudeng sama internet."

Masyarakat tidak tahu bagaimana cara menggunakan teknologi dan apa manfaat bagi mereka dengan mengakses informasi dari website. Karena bagi mereka, lebih baik langsung datang ke kantor. Meskipun lebih lama prosesnya, tapi masyarakat lebih paham dan mengerti apa yang mereka butuhkan. Salah satu penghambat bagi masyarakat, karena masih banyak masyarakat tidak paham tentang e-gov dan tidak adanya perangkat yang dimiliki. Hanya beberapa orang yang bisa mengakses hal yang begituan.

Berdasarkan hasil wawancara dapat diketahui kendala yang menghambat dalam pengembangan e-gov di Kabupaten Padang Pariaman yaitu kurang adanya kesadaran dari masyarakat untuk mendukung terlaksananya e-gov. Masyarakat Kabupaten Padang Pariaman yang belum sepenuhnya melek komputer ataupun internet.

Temuan ini sejalan dengan hasil penelitian yang dilakukan Sudrajat dkk: 2015; Sosiawan: 2008 mengungkapkan bahwa kendala dalam penerapan e-gov itu karena masyarakatnya. Masyarakat masih belum meratanya literacy masyarakat dengan pemanfaatan e-gov karena mayoritas penduduk yang bisa mengakses internet penduduk yang berada di golongan atas. Persepsi masyarakat akan Information and communications technology (ICT) akan mempengaruhi kemauan menggunakan Information and communications technology (ICT).

\section{SIMPULAN, KETERBATASAN DAN SARAN \\ Simpulan}

Berdasarkan hasil pembahasan dapat diperoleh kesimpulan sesuai dengan rumusan masalah penelitian ini, yaitu pengembangan e-government yang dilakukan pemerintah daerah dan faktor atau kendala apa saja dalam menghambat penerapan e-government. Penelitian ini mendukung penelitian Nugraha (2018) bahwa pengembangan e-government untuk daerah sendiri masih belum optimal.

Pengembangan $e$-gov di kabupaten Padang Pariaman masih belum optimal, tidak sesuai dengan apa yang diharapkan. Hal ini dapat dapat dilihat dari elemen-elemen kesuksesan penerapan e-government yang wajib dimiliki oleh pemerintah. Elemen-elemen tersebut terbagi menjadi tiga yaitu elemen support, capacity, dan value. Berdasarkan penelitian diketahui dari ketiga elemen tersebut, dua diantaranya yaitu elemen support dan capacity belum mendukung dalam pengembangan e-gov, sedangkan satu elemen yakni value sudah mendukung. Egovernment memberikan manfaat baik itu kepada pemerintah yakni pemerintah dapat meningkatkan transparansi dengan publikasi melalui website dari pemerintah Kabupaten Padang Pariaman dapat mempublikasikan berita maupun laporan-laporan keuangan, e-gov juga bermanfaat untuk meningkatkan pelayanan kepada masyarakat, serta untuk mewujudkan good governance. Sedangkan manfaat yang diperoleh masyarakat yakni melalui website masyarakat dapat memperoleh informasi secara lebih cepat dan lebih murah. 
Masyarakat dapat mengakses informasi secara online tanpa harus datang langsung ke instansi terkait. Kendala yang dihadapi pemerintah dalam mengembangkan e-gov, yaitu: Belum kuatnya payung hukum terkait penerapan e-government di Pemerintah Padang Pariaman., terbatasnya sumber daya manusia baik dari secara kualitas maupun kuantitas karena beberapa pegawai ditempatkan tidak sesuai dengan kompetensi yang dimiliki, Terbatasnya sumber daya finansial, Kurangnya sosialisasi kepada masyarakat sehingga masih banyak masyarakat yang belum tahu layanan e-government. Berbagai kendala yang diharapi pemerintah. Ada dua faktor kendala yang dihadapi pemerintah. Selain kendala internal, pemerintah juga mengalamai hambatan disebabkan faktor eksternal yaitu masyarakat yang sebagai pengguna layanan fasilitas e-gov. Kurang adanya kesadaran dari masyarakat untuk mendukung terlaksananya e-gov. Hal ini terbukti karena masyarakat Kabupaten Padang Pariaman belum sepenuhnya melek komputer ataupun internet. Keterbatasan kemampuan ini disebabkan oleh budaya yang hidup di masyarakat yang terbiasa menggunakan cara manual daripada menggunakan media elektronik.

\section{Keterbatasan}

Keterbatasan dalam penelitian ini adalah dalam hal informan. Informan yang dipilih adalah kepala bidang, kasi dan masyarakat. Tidak dapat menemui informan lebih banyak seperti pegawai dinas kominfo. Karena hanya beberapa orang yang bisa memberikan informasi disebabkan kesibukan pekerjaan. Pegawai disibukkan dengan agenda rapat dan adanya pelatihan yang diadakan. Kemudian penelitian kesulitan mencari informan masyarakat yang sudah pernah mengakses website.

\section{Saran}

Penelitian ini bertujuan untuk mengidentifikasi pengembangan e-government yang dilakukan pemerintah dan apa saja kendala/hambatan dalam penerapan e-government di Kabupaten Padang Pariaman. Permasalahan yang ditemukan dari hasil penelitian diharapakan dapat berguna sebagai bahan evaluasi bagi pemerintah sendiri agar e-government ini dapat dilaksanakan sebaik mungkin. Saran yang penulis berikan berdasarkan hasil penelitian ini yaitu:

1. Penelitian Selanjutnya

Berdasarkan keterbatasan penelitian, maka saran untuk penelitian selanjutnya adalah sebaiknya meneliti kepada masing-masing OPD, kendala yang dirasakan dalam penerapan $e$ gov. Lebih baik OPD yang dipilih lebih tersebar dan hanya 1 orang yang diwawancarai masing-masing OPD demi mendapatkan data yang jauh lebih kaya dan mendalam. Pemilihan OPD akan lebih baik jika lebih bervariasi. Penelitian selanjutnya hendaknya berfokus pada pemerintahan kota/kabupaten lain atau bisa dalam ruang lingkup provinsi karena beda daerah bisa saja berbeda permasalahan yang ditemukan.

2. Pemerintah Kabupaten Padang Pariaman

a. Pemerintah Kabupaten hendaknya melaksanakan pelatihan tentang E-government sesering mungkin, sehingga seluruh aparatur benar-benar paham hakikat yang sesungguhnya dari e-government.

b. Pemerintah kabupaten perlu menata kembali penempatan posisi dari aparatur dan menyesuaikan jabatan aparatur dengankompetensi yangdimiliki.

c. Peraturan seharusnya tidak dipandang sebagai halangan dalam bekerja, akan tetapi peraturan membantu memberikan fleksibelitas dalam pelaksanaankegiatan.

d. Kepala-kepala OPD harus lebih kreatif dan inovatif lagi dalam merumuskan mata 
anggaran setiap tahunnya dan janganpernah takut untuk melakukan suatu perubahan demi tercapainya tujuan jangka panjangpemerintah.

e. Pemerintah daerah dan masing-masing OPD harus melakukan sosialisasi secara rutin kepada masyarakat tentang adanya e-government Tidak hanya dari media publik sebaiknya pemerintah mengadakan sosialisasi yang mempertemukan langsung antara pemerintah dan masyarakat.

f. Pemerintah Kabupaten sebaiknya dapat meningkatkan infrastruktur seperti penambahan server, area hotspot, penambahan bandwitch serta mengkoneksikan seluruh SKPD yang ada di Kabupaten Padang Pariaman.

\section{DAFTAR PUSTAKA}

Agustin, Henri. (2014). Publikasi Dokumen Pengelolaan Anggaran pada Website Pemkab/Pemkot di Propinsi Sumatera Barat. Seminar Nasional Aplikasi Teknologi Informasi (SNATI). Yogyakarta. A7-12.

Agustin, Henri; Halmawati. (2017). Local Government Resistance on Implementation of Minister of Internal Affair Instruction Number 188.52/1797/SJ/2012 About Transparency in Public Budgeting Management: Evidence From West Sumatera Province, Indonesia. The $1^{\text {st }}$ Unimed International Conference on Economics and Business. Medan. 7.

Alshawi, S., \& Alalwany, H. (2009). E-government Evaluation Factors: Citizen's Perspective. Information Technology for Development, 193-208.

Arif, M. S., Larasati, E., \& Rihandoyo.(2013). Analisis Pengembangan Electronic Government Melalui Penyelenggaraan Website di Kabupaten Kudus. Journal Of Public Policy And Management Review, 2(4).

Basu, S. (2004). E-government and Developing Countries: An Overview. International Review of Law Computers \& Technology, 1009-132.

Cynthia, Warsono, H., \& Mustam, M. (2015). Analisis Pengembangan E-government di Pemerintahan Kota Tangerang. Journal Of Public Policy And Management Review, 4.

Gao, X., Song, Y., \& Zhu, X. (2013). Intergration and Coordination: Advancing China's Fragmented E-government to Holistic Governance. Government Information Quarterly 30 (2), 173-181.

Habibullah, A. (2010). Kajian Pemanfaatan dan Pengembangan E-Governmet, 23 (3), 187-195

Heeks, R. (2003). Most E-government-For-Development Project Fail: How Can Risks be Reduced? iGovernment Working Paper Series (pp. 1-17). Manchester: Institute for Development Policy and Management.

Instruksi Presiden No. 6 tahun 2001 Tentang Telekomunikasi, Media Dan Teknologi Informasi.

Instruksi Presiden RI No.3 Tahun 2003 Tentang Kebijakan Dan Strategi Nasional Pengembangan E-government.

Indrajit, R. E. (2006). Electronic Government. Yogyakarta: Andi.

Irawan, A. (2018). Sistem Pelayanan Publik Berbasis E-Government Pada Pemerintah Daerah Kabupaten Merauke. e-Journal Unmus, 7, 20-37.

Isni, A. R. (2018). Analisis Kualitas Website Pemerintah Daerah Pada Kabupaten se-Sumatera Barat. e-Journal UNP.

Kumorotomo, W. (2010). Kegagalan Penerapan E-Government dan Kegiatan Tidak Produktif dengan Internet. Yogyakarta

Mardiasmo. (2009). Akuntansi Sektor Publik. Jakarta: Salemba Empat. 
Moon, M., \& Norris , D. (2005). Does managerial orientation matter? The adoption of reinventing government at the municipal level. Infromation Systems Journal, 15(1), 4360.

Nkohkwo, Q.-a., \& Islam, M. (2013). Challenges to the Successful Implementation of Egovernment Initiatives in Sub-Saharan Africa: A Literature Review. Electronic Journal of E-government 11(2), 253-267.

Nugraha, J. T.(2018) .E-government dan Pelayanan Publik (Studi Tentang Elemen Sukses Pengembangan E-Governmentdi Pemerintah Kabupaten Sleman). Journal Of Communication And Media Study 2(1), 32-42.

Ordiyasa, I. W. (2015). Kegagalan Penerapan E-Government di Negara-Negara Berkembang. Seminar Nasional Teknologi Informasi dan Multimedia, (pp.55-60). Yogyakarta.

Puspa, R. A., \& Hariani, D. Analisis Pengembangan Electronic Government di Dinas Pendidikan dan Kebudayaan Provinsi Jawa Tengah. Diponegoro Journal Of Accounting, 1-16

Puspita, R., \& Martani, D. (2012). Analisis Pengaruh Kinerja dan Karakteristik Pemerintah Daerah Terhadap Tingkat Pengungkapan dan Kualitas Informasi dalam Website Pemerintah Daerah. Simposium Nasional Akuntansi XV (pp. 1-25). Banjarmasin: IAI.

Ramon, J. G.,\& Pardo, T. A. (2005). E-government Success Factors : Mapping Practical Tools to Theoretical Foundations. Government Information Quarterly 22, 187-216

Retnowati, N. D., \& Retnowati, D. (2008). Peranan E-Government dalam Mewujudkan Good Governance Bagi Masyarakat. Seminar Nasional Informatika, (pp. 205-211)

Rahman, A. (2011). Evaluasi Kesuksesan E-Government :Studi di Kabupaten Sleman dan Kabupaten Tulungagung. Indonesian Journal of Accounting and Auditing (JAAI). 15 (2), 190-203.

Sari, K. D., \& Winarno, K. A. (2012). Implementasi E-government System Dalam Upaya Peningkatan Clean And Good Governance di Indonesia. Journal Ekonomi Akuntansi dan Manajemen Vol XI.

Sosiawan, E. A. (2008). Tantangan dan Hambatan Dalam Implementasi E-Government di Indonesia. Seminar Nasional Informatika, (pp. 99-108). Yogyakarta.

Sugiono. (2014). Memahami Penelitian Kualitatif. Bandung: Alfabeta.

Sudrajat, R. K., Setyowati, E., \& Sukanto. (2015). Efektivitas Penyelenggaraan E-Government Pada Badan Pelayanan Perizinan Terpadu Kota Malang. Journal of Public Administration (JAP), 3(12), 2145-2151.

Yunita, N. P., \& Aprianto, R. (2018). Kondisi Terkini Perkembangan Pelaksanaan EGovernment di Indonesia: Analisis Website. Seminar Nasional Teknologi Informasi dan Komunikasi, (pp.329-336). Yogyakarta 